University of Nebraska - Lincoln

DigitalCommons@University of Nebraska - Lincoln

Agronomy \& Horticulture -- Faculty Publications

Agronomy and Horticulture Department

2012

\title{
Expected Economic Potential of Substituting Legumes for Nitrogen in Bermudagrass Pastures
}

Jon T. Biermacher

Samuel Roberts Noble Foundation, Ardmore, OK, jtbiermacher@noble.org

The Samuel Roberts Noble Foundation, Inc. Reuter

The Samuel Roberts Noble Foundation, Inc.

M.K. Kering

The Samuel Roberts Noble Foundation, Inc.

J.K. Rogers

The Samuel Roberts Noble Foundation, Inc.

J. Blanton Jr

The Samuel Roberts Noble Foundation, Inc.

See next page for additional authors

Follow this and additional works at: https://digitalcommons.unl.edu/agronomyfacpub

Part of the Plant Sciences Commons

Biermacher, Jon T.; The Samuel Roberts Noble Foundation, Inc. Reuter; Kering, M.K.; Rogers, J.K.; Blanton, J. Jr; Guretzky, John A.; and Butler, T.J., "Expected Economic Potential of Substituting Legumes for Nitrogen in Bermudagrass Pastures" (2012). Agronomy \& Horticulture -- Faculty Publications. 601. https://digitalcommons.unl.edu/agronomyfacpub/601

This Article is brought to you for free and open access by the Agronomy and Horticulture Department at DigitalCommons@University of Nebraska - Lincoln. It has been accepted for inclusion in Agronomy \& Horticulture -Faculty Publications by an authorized administrator of DigitalCommons@University of Nebraska - Lincoln. 


\section{Authors}

Jon T. Biermacher; The Samuel Roberts Noble Foundation, Inc. Reuter; M.K. Kering; J.K. Rogers; J.

Blanton Jr; John A. Guretzky; and T.J. Butler 


\title{
Expected Economic Potential of Substituting Legumes for Nitrogen in Bermudagrass Pastures
}

\author{
Jon T. Biermacher, ${ }^{\star}$ Ryan Reuter, Maru K. Kering, \\ James K. Rogers, John Blanton, Jr., John A. Guretzky, and Twain J. Butler
}

\begin{abstract}
Grazing warm-season grass pastures with stocker cattle (Bos taurus) is an important economic activity in the southern Great Plains, and substantial increases in the price of $\mathrm{N}$ fertilizer have negatively affected profitability of forage producers. The goal of the study was to determine if bermudagrass [Cynodon dactylon (L.) Pers.] pastures interseeded with either annual or perennial legumes are more profitable than the conventional method of fertilizing with $112 \mathrm{~kg} \mathrm{~N} \mathrm{ha}^{-1}$ commercial fertilizer. A completely randomized design grazing study was conducted in south-central Oklahoma during the spring and summer months of 2008 , 2009, and 2010. Preconditioned stocker cattle $\left(260 \pm 47 \mathrm{~kg} \mathrm{head}^{-1}\right)$ were randomly assigned to pastures $(1.42 \pm 0.10$ ha; three replicates per system) at $2.32 \pm 0.40$ animals ha ${ }^{-1}$, beginning when measured standing forage reached $2000 \mathrm{~kg} \mathrm{ha}^{-1}$ and grazing continuously until forage mass declined to $1000 \mathrm{~kg} \mathrm{ha}^{-1}$. Results of the $3-\mathrm{yr}$ grazing study show that under continuous stocking for the growing conditions common to the south-central Great Plains, the legume systems could not compete economically with the common practice of fertilizing bermudagrass pastures with synthetic inorganic $\mathrm{N}$ fertilizer. Results are most sensitive to number of grazing days, price of $\mathrm{N}$, and prices of legume seed.
\end{abstract}

J.T. Biermacher, R. Reuter, M.K. Kering, J.K. Rogers, J. Blanton, Jr., and T.J. Butler, The Samuel Roberts Noble Foundation, Inc., Ardmore, OK 73401; J.A. Guretzky, Dep. of Horticulture and Agronomy, Univ. of Nebraska, Lincoln, NE 68583-0915. Received 25 Aug. 2011. ^Corresponding author (jtbiermacher@noble.org).

Abbreviations: ADF, acid detergent fiber; BG-A, bermudagrass interseeded with alfalfa; BG-CV, bermudagrass interseeded with clover and vetch; BG-N, bermudagrass plus $112 \mathrm{~kg} \mathrm{~N}$ ha $^{-1}$ from urea; CP, crude protein; IVDMD, in vitro dry matter digestibility; LR, likelihood ratio; NDF, neutral detergent fiber; NIRS, near-infrared reflectance spectroscopy; PLS, pure live seed.

RAZING warm-season perennial grass with stocker cattle (Bos

J taurus) is an important economic activity in the south-central Great Plains. Synthetic sources of $\mathrm{N}$ are commonly used to supply $\mathrm{N}$ fertilizer requirements to bermudagrass [Cynodon dactylon (L.) Pers.] pastures in the region. According to the Oklahoma Cooperative Extension Service $\mathrm{N}$ fertilizer typically accounts for up to $30 \%$ of total production cost in the region (OCES, 2012). However, over the past several years, prices for synthetic sources of $\mathrm{N}$ have trended increasingly higher. In fact, the price for $\mathrm{N}$ fertilizer increased by 120\% between 2000 and 2007 (USDA, 2009). These higher prices have weighed heavily on farm profitability of forage producers. With this strain on farm profitability, producers are searching for potential alternative strategies for managing $N$ fertilizer requirements for their introduced warm-season forages.

Interseeding legume crops into grass pastures is not an innovative concept. In fact, a substantial amount of information currently exists regarding the various biological aspects of legume-grass pastures. For example, Baylor (1974) observed increases in forage

Published in Crop Sci. 52:1923-1930 (2012).

doi: 10.2135/cropsci2011.08.0455

Freely available through the author-supported open-access option.

(C) Crop Science Society of America | 5585 Guilford Rd., Madison, WI 53711 USA

All rights reserved. No part of this periodical may be reproduced or transmitted in any form or by any means, electronic or mechanical, including photocopying, recording, or any information storage and retrieval system, without permission in writing from the publisher. Permission for printing and for reprinting the material contained herein has been obtained by the publisher. 
yield and quality and a better distribution of available forage for grass pasture interseeded with legumes compared to only grass pastures. Rao et al. (2007) reported that grass pea (Lathyrus sativus L. 'AC-Greenfix') interseeded into established stands of bermudagrass resulted in yields comparable to bermudagrass receiving $45 \mathrm{~kg} \mathrm{~N} \mathrm{ha}^{-1} \mathrm{yr}^{-1}$ and that the yield and in vitro dry matter digestibility (IVDMD) was significantly greater than unfertilized bermudagrass. It was also reported that interseeded legumes increased forage relative feed value, supplied fixed $\mathrm{N}$ to the soil, and decreased $\mathrm{N}$ fertilizer requirements (Hoveland, 1989). Cassida et al. (2006) reported that bermudagrass interseeded with alfalfa (Medicago sativa L.) produced a longer grazing period than alfalfa alone. Moreover, they also reported that alfalfa produced a greater quantity of biomass early in spring while bermudagrass produced greater amounts of biomass during the summer months, suggesting that a cool-season legume interseeded into established stands of bermudagrass may allow for a better distribution of high quality forage over a longer grazing period. In addition, grazing-type alfalfa cultivars (Smith and Bouton, 1993; Bouton and Gates, 2003) may be better suited than conventional hay-type cultivars in grazing systems.

Despite the multitude of research studies that have been conducted to investigate the biological effects of using interseeded, $\mathrm{N}$-fixing legumes in established stands of introduced perennial grasses, there remains limited information available regarding the economic potential of using such forage systems as a substitute for the common practice of applying synthetic sources of $\mathrm{N}$. Therefore, the objectives of this research were (i) to determine the effects of $\mathrm{N}$ supply system on forage yield, forage quality, and animal performance measures and (ii) to determine if either of two alternative legume systems (annual or perennial) is expected to be more profitable than the conventional $\mathrm{N}$ management strategies commonly used in the region. Given the expected increase in management intensity required to implement the alternative legumebased systems, estimates of the expected relative economic profitability of the two alternative systems are considered necessary to facilitate adoption by farmers. Economic information would provide plant, soil, and livestock scientists a better understanding of how management practices should be adjusted to glean the optimum net economic benefits from the legume-based systems.

\section{MATERIALS AND METHODS Site Description}

The grazing experiment was conducted during the 2008, 2009, and 2010 production seasons via a completely randomized designed experiment with three treatments and three replications at The Samuel Roberts Noble Foundation's Pasture Research and Demonstration Farm $\left(34^{\circ} 13^{\prime} \mathrm{N}\right.$, 97 ${ }^{\circ} 12^{\prime}$ $\mathrm{W}$, and elevation $266 \mathrm{~m}$ ) in south-central Oklahoma. This study site included a 12.8-ha established stand of bermudagrass partitioned into nine $(1.42 \pm 0.10 \mathrm{ha})$ grazing paddocks on a Weatherford fine sandy loam (fine-loamy, siliceous, active, thermic ultic haplustalfs) with average $\mathrm{pH}$ of 5.9 , organic matter of $20 \mathrm{~g} \mathrm{~kg}^{-1}$, and $5 \mathrm{mg} \mathrm{NO}-\mathrm{N} \mathrm{kg}^{-1}$. The average MehlichIII extractable soil $\mathrm{P}, \mathrm{K}, \mathrm{Ca}$, and $\mathrm{Mg}$ were $24,102,504$, and $175 \mathrm{mg} \mathrm{kg}^{-1}$, respectively. Treatments included three $\mathrm{N}$ supply systems: bermudagrass plus $112 \mathrm{~kg} \mathrm{~N} \mathrm{ha}^{-1}$ from urea (BG-N), bermudagrass interseeded with clover and vetch (BG-CV), and bermudagrass interseeded with alfalfa (BG-A). The land area used for this study site was planted to 'Midland' bermudagrass in 1965 in an attempt to mitigate soil erosion resulting from continuous cropping activities commonly pursued in the region. Beginning in 1989 and continuing through the onset of this study, the land was used to demonstrate intensive rotational grazing practices for cow-calf and stocker enterprises. Further details about the site are reported by Dalrymple (1998).

\section{Forage Management}

Bermudagrass was hayed to a 5.1-cm stubble height in September 2007 to reduce residual herbage mass and enhance seedling competitiveness. In October of each year, a mix of legume seed was no-till drilled (Great Plains Mfg.) a single time into the existing bermudagrass sod in the BG-CV paddocks in 19.1-cm rows. The legume seed mix consisted of $12.3 \mathrm{~kg} \mathrm{ha}^{-1}$ pure live seed (PLS) 'AU Early Cover' hairy vetch (Vicia villosa Roth), $9.4 \mathrm{~kg} \mathrm{ha}{ }^{-1}$ PLS 'Dixie' crimson clover (Trifolium incarnatum L.), and $5.8 \mathrm{~kg} \mathrm{ha}^{-1}$ PLS 'Apache' arrowleaf clover (Trifolium vesiculosum Savi). Vetch was drilled at a $2.5-\mathrm{cm}$ depth while clovers were drilled at a $0.64-\mathrm{cm}$ depth (i.e., clovers were delivered via the small seed box on the no-till drill).

'Bulldog 505' alfalfa (9.9 kg PLS ha ${ }^{-1}$ ) was no-till drilled into the existing bermudagrass sod in the BG-A paddocks in 19.1-cm rows in October 2007. Seeding depth for alfalfa was $0.64 \mathrm{~cm}$. Stand failures of alfalfa in the three BG-A paddocks in the fall of 2007 resulted in alfalfa being replanted in September 2008. These stand failures were attributed to poor soil contact of alfalfa seed drilled in 2007 due to a 1.3-cm layer of bermudagrass thatch and $58 \%$ below normal precipitation during the autumn establishment period. In February of each year, the BG-CV and BG-A systems were sprayed with imazamox 2-[4,5-dihydro-4-methyl-4(1-methylethyl)-5-oxo-1H-imidazol-2-yl]-5-(methoxymethyl)-3-pyridinecarboxylic acid at a rate of $0.04 \mathrm{~kg}$ a.i. ha ${ }^{-1}$ to control broadleaf weeds, and glyphosate $\mathrm{N}$-(phosphonomethyl) glycine was applied at $1.12 \mathrm{~kg}$ a.i. $\mathrm{ha}^{-1}$ to paddocks assigned to the BG-N system to control broadleaf weeds and cool-season annuals such as ryegrass (Lolium perenne L.) and cheatgrass (Bromus tectorum L.). In March of each year, $112 \mathrm{~kg} \mathrm{~N} \mathrm{ha}^{-1}$ (as urea; 46-0-0) was applied to the BG-N system. All paddocks received annual spring applications of $100 \mathrm{~kg} \mathrm{ha}^{-1}$ of $\mathrm{P}_{2} \mathrm{O}_{5}$ according to soil test recommendations for optimal legume production (Zhang et al., 2009).

Forage samples were collected at 14-d intervals during the grazing trial by clipping six quadrats $\left(0.09 \mathrm{~m}^{2}\right)$ at random locations (locations were not resampled) in each paddock to a stubble height of $2.54 \mathrm{~cm}$. Forage samples were dried in a forced draft oven at $50^{\circ} \mathrm{C}$ to a constant weight, ground in a Wiley mill (ThomasWiley Laboratory Mill, Thomas Scientific) to pass a 1-mm screen, and analyzed for crude protein (CP), acid detergent fiber (ADF), 
neutral detergent fiber (NDF), and IVDMD concentrations using the Foss 6500 near-infrared reflectance spectroscopy (NIRS) instrument. The samples were scanned using Foss ISI Scan software and prediction equations developed by the NIRS Forage and Feed Testing Consortium (Hillsboro, WI). The CP mean, standard error of validation, and $r^{2}$ for the equation used were $125 \mathrm{~g} \mathrm{~kg}^{-1}, 8 \mathrm{~g} \mathrm{~kg}^{-1}$, and 0.98 , respectively. The ADF mean, standard error of validation, and $r^{2}$ for the equation used were $401 \mathrm{~g}$ $\mathrm{kg}^{-1}, 16 \mathrm{~g} \mathrm{~kg}^{-1}$, and 0.95, respectively. The NDF mean, standard error of validation, and $r^{2}$ for the equation used were $601 \mathrm{~g} \mathrm{~kg}^{-1}$, $21 \mathrm{~g} \mathrm{~kg}^{-1}$, and 0.97 , respectively. The IVDMD mean, standard error of validation, and $r^{2}$ for the equation used were $679 \mathrm{~g} \mathrm{~kg}^{-1}$, $33 \mathrm{~g} \mathrm{~kg}^{-1}$, and 0.88 , respectively. These equations were then used to predict CP, ADF, NDF, and IVDMD for all samples.

\section{Cattle Management}

It is noteworthy to point out that stocker cattle grazing experiments provide several challenges over and above those of conventional crop experiments. For instance, it is often difficult to a priori determine the optimum number of animals to place on the individual paddocks. If too few animals are allocated, forage will go unused. If too many animals are allocated, gains may be low and could be negative if the forage is insufficient for animal maintenance requirements. This uncertainty can translate into challenges in determining when to initiate and terminate grazing. In addition, it is important to consider animal type and weight, purchase dates, and pretrial management. In each year of this study, commercial stocker steers (approximately 180 to $270 \mathrm{~kg}$ body weight) of predominately Angus breeding were purchased from local auction barns and then preconditioned for $45 \mathrm{~d}$ to prepare them for grazing. This cattle type was selected to mimic typical producers' practices in the region traditionally used for grazing the conventional (BG-N) forage system. Preconditioning included individual identification, anthelmintic treatment, implant administration, vaccination, and surgical castration and dehorning as needed. During the receiving period, calves were fed a mineral supplement and ad libitum rye (Secale cereale L.) hay. Each paddock was managed independently in each production year of this study. Grazing was initiated for each paddock when measured standing forage reached $2000 \mathrm{~kg} \mathrm{ha}^{-1}$. At grazing initiation, each paddock was stocked with four steers in 2008 and three steers in 2009 and 2010. However, steers in 2008 were lighter $(220 \mathrm{~kg})$ than steers in 2009 and $2010(286 \mathrm{~kg})$, resulting in a similar forage allowance across years $(3.0$ to $3.8 \mathrm{~kg}$ of available forage dry matter per kilogram of steer body weight at turnout). Cattle grazing was terminated when available forage fell below $1000 \mathrm{~kg} \mathrm{ha}^{-1}$ or when forage quality was estimated to limit animal performance (in some cases the BG-N system was not reduced to the $1000 \mathrm{~kg}$ threshold due to forage production exceeding the demand of our fixed stocking rate). During the grazing period for each year of the study, steers had ad libitum access to a loose mineral containing monensin during the experiment. In addition, steers in legume-containing paddocks had access to poloxalene blocks as a bloat preventative. During the experimental grazing period, steers were weighed every $28 \mathrm{~d}$. To minimize effects of differences in gut fill, body weights of all steers were recorded following a 16-h period in a "drylot" adjacent to the study site during which feed and water were withheld.

\section{Economic Analysis}

The relative expected profitability for each of the $\mathrm{N}$ management systems was determined by calculating the expected revenues and costs associated with each of the production practices for each system. Only those costs that varied due to differences in production practices between systems were considered in the analysis (Table 1). These costs include quantity of $\mathrm{N}$ and $\mathrm{N}$ application, seed, establishment, herbicide and herbicide application, and opportunity cost of capital. Three-year average costs for each system were summed and then subtracted from the expected revenue generated from marketing the total kilograms of gain per hectare produced in each of the three systems. Note that establishment costs for the perennial alfalfa system were amortized over the 3-yr life of the stand realized in the study. Expected local prices for the 2011 production year were used for all inputs, including $\mathrm{N}$ fertilizer, herbicides, and legume seeds, and an annual percentage rate of $7.5 \%$ was used to calculate opportunity cost of capital and the amortized payment for the BG-A system. Custom rates for $\mathrm{N}$ application, no-till legume establishment, and herbicide application were taken from Doye and Sahs (2010).

Expected revenue for each system was calculated as the 3-yr average total gain $\left(\mathrm{kg} \mathrm{ha}^{-1}\right)$ times the expected value of gain (US\$ $\mathrm{kg}^{-1}$ ). Due to the nature of forage availability between systems, cattle placement dates and removal dates differed. Due to this difference, it is entirely possible that value of gain could be different between systems grazing systems due to differences in purchase and selling price of cattle. Expected value of gain was calculated for cattle in each system and year as the difference between ending value of cattle (final price multiplied by final weight) and beginning value (initial price times initial weight) divided by total gain per head. We assume that before the beginning of the production year, producers will use quoted futures prices along with the 3-yr average total gain to estimate the expected value of gain for each system. In fact, many commercial producers in the region will probably use futures price information to engage in a hedge to lock in purchase and sale prices for their cattle. For this study, expected value of gain $\left(\$ \mathrm{~kg}^{-1}\right)$ was determined using cattle prices quoted in 2011 by the Chicago Mercantile Exchange and adjusted to reflect Oklahoma City National Stockyard regional prices using BeefBasis.com (Crosby et al., 2005).

Table 1. Prices for $\mathrm{N}$ fertilizer, herbicides, legume seeds, and custom rates for $\mathrm{N}$ and herbicide application and no-till drilling.

\begin{tabular}{lr}
\hline \multicolumn{1}{c}{ Input description } & Price $^{\dagger}$ \\
\hline Urea $(46-0-0)\left(\$ \mathrm{~kg}^{-1}\right)$ & 1.21 \\
Glyphosate $\left(\$ \mathrm{~L}^{-1}\right)$ & 7.93 \\
Imazamox $\left(\$ \mathrm{~L}^{-1}\right)$ & 141.65 \\
Crop oil $\left(\$ \mathrm{~L}^{-1}\right)$ & 1.95 \\
Crimson clover seed $\left.\left(\$ \mathrm{~kg}^{-1} \mathrm{PLS}\right)^{\ddagger}\right)$ & 3.73 \\
Arrowleaf clover seed $\left(\$ \mathrm{~kg}^{-1} \mathrm{PLS}\right)$ & 7.25 \\
Hairy vetch seed $\left(\$ \mathrm{~kg}^{-1} \mathrm{PLS}\right)$ & 4.65 \\
Alfalfa seed $\left(\$ \mathrm{~kg}^{-1} \mathrm{PLS}\right)$ & 17.97 \\
Custom N application rate $(\$$ ha & -1 \\
Custom herbicide application rate $\left(\$ \mathrm{ha}^{-1}\right)$ & 12.35 \\
Custom no-till drill legumes seed rate $\left(\$ \mathrm{ha}^{-1}\right)$ & 12.35 \\
\hline
\end{tabular}

${ }^{\dagger}$ Market prices for $\mathrm{N}$, herbicides and legume seeds were obtained from local farm input suppliers in April 2011 and custom rates were taken from Doye and Sahs, 2010. ‡PLS, pure live seed. 
There has been significant volatility in market prices of cattle, fertilizer, and legume seed over the past several years. As a result of this volatility, using historical prices to estimate expected revenues and costs can be misleading. Due to this volatility, it is especially important to understand how sensitive the economic results are to potential variations in our assumptions about expected prices and other factors such as the expected life of the alfalfa stand and the cost of establishing alfalfa. Therefore, sensitivity analysis was used to determine the break-even prices of $\mathrm{N}$, legume seed, and the break-even life of the alfalfa stand. Break-even prices in this context serve as price thresholds that allow producers to make more informed decisions about whether or not to adopt one of the legume-based systems based in favor of the control system. In addition, we also evaluate the sensitivity of the results to assumptions about the cost of establishing alfalfa and potential differences in value of gain between systems that are due to purchase and sale prices for cattle.

\section{Statistical Model}

Forage and animal performance data collected from the experiment and economic calculations (value of gain, gross revenue, cost, and net return) were analyzed using random-effects mixed models using the MIXED Procedure of SAS (SAS Institute, 2002) with paddock (replication) and growing season (year) as random effects and treatment (system) as a fixed effect. The statistical models applied the autoregressive (AR1) spatial power covariance structure to help account for temporal autocorrelation in data collected across growing periods. Individual paddocks (replicates) were used as local subjects within all analyses, because they represented the units in the study that received the specified management practices (treatments) over the course of the study. The null hypothesis of no production year random effects was tested with the likelihood ratio (LR) test and rejected at $p \leq 0.0001$ for all dependant variables analyzed. The
LR ( $\lambda$ ) was obtained as a ratio of the maximum likelihood value obtained when the mixed model was analyzed with and without the random constraint associated with the production year. The LR depended on the restricted and unrestricted models and under regularity, the test statistic $(-2 \ln \lambda)$ followed a chi-squared distribution with a degrees of freedom equal to the number of restrictions imposed (Greene, 2005).

\section{RESULTS AND DISCUSSION}

\section{Precipitation}

Precipitation during September through November of the initial establishment year (2007) for the legumes was $58 \%$ below the 30-yr average. During the first and third seasons of grazing (2008 and 2010), precipitation was 33 and $10 \%$ below average while precipitation in the second season (2009) was 18\% above average (Fig. 1).

\section{Forage Mass and Nutritive Value}

Forage mass of legumes (clover-vetch and alfalfa) and bermudagrass was affected by evaluation date; therefore, means are reported by forage system and harvest season (Fig. 2). Forage mass of legumes was generally greater during April and May while bermudagrass mass was greater during June, July, and August. This resulted in 90 to 208\% greater total forage mass in April and 20 to 100\% greater forage mass in May for the legume systems. Total mass for the legume systems (BG-CV and BG-A) were 49 to $55 \%$ less than total mass in the BG-N system for June and July. This could be attributed to reduced bermudagrass growth as a result of competition from the legumes. Total mass did not differ between BG-N and BG-CV during August and September, which would

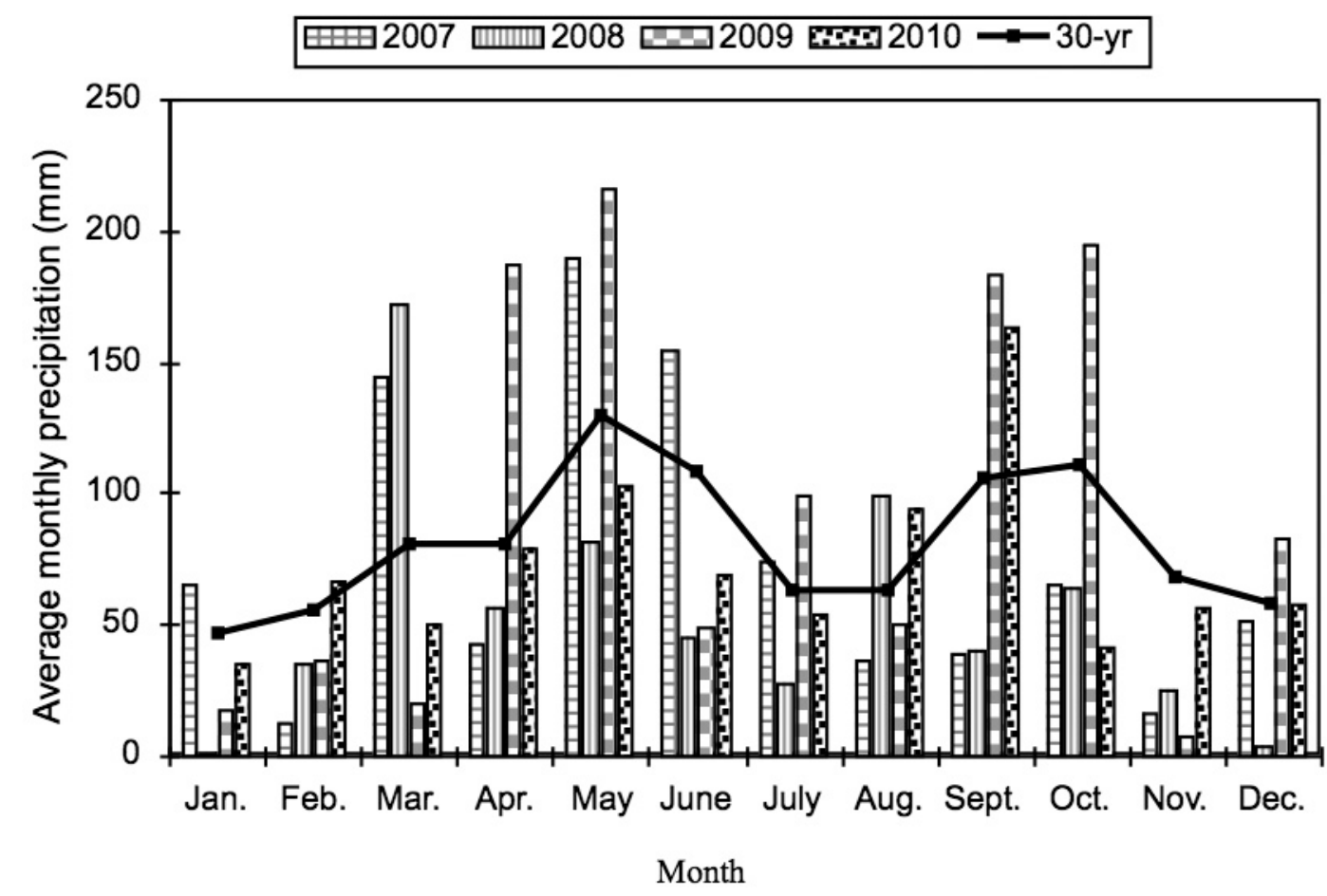

Figure 1. Monthly rainfall (mm) for the 2007 to 2010 growing seasons at Ardmore, OK, compared to the 30-yr average. 

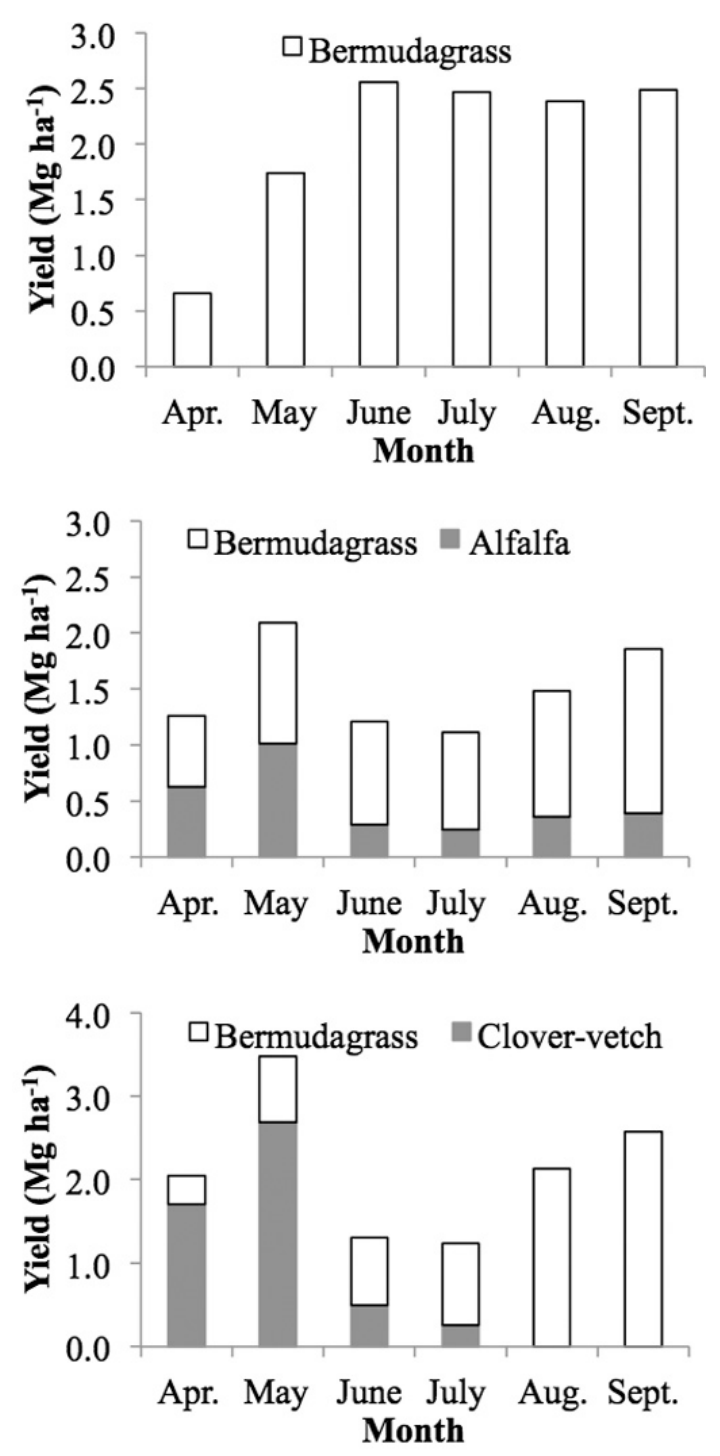

Figure 2. Seasonal changes in forage mass for bermudagrass only, bermudagrass-alfalfa, and bermudagrass-vetch-clover systems averaged across the 2008, 2009, and 2010 growing seasons.

suggest that $\mathrm{N}$ may have been recycled through grazing these annual legumes. Forage mass was lowest in the BG-A system during June through September, which suggests that alfalfa is not competitive with bermudagrass under continuous grazing or the cattle preferentially grazed the alfalfa.

Nutritive value (CP, ADF, and IVDMD) was also affected by evaluation date; therefore, means are reported by system and harvest season (Fig. 3). Nutritive value generally decreased over time as plants matured. Crude protein values declined from April (179 to $237 \mathrm{~g} \mathrm{~kg}^{-1}$ ) to September (115 to $\left.141 \mathrm{~g} \mathrm{~kg}^{-1}\right)$. A notable difference occurred in the BG-CV system, in which nutritive values exhibited a wavelike pattern. Nutritive value decreased from April (ADF of $273 \mathrm{~g} \mathrm{~kg}^{-1}$ and IVDMD of $841 \mathrm{~g} \mathrm{~kg}^{-1}$ ) to June (ADF of $375 \mathrm{~g} \mathrm{~kg}^{-1}$ and IVDMD of $679 \mathrm{~g} \mathrm{~kg}^{-1}$ ). Nutritive value then increased in July (ADF of $328 \mathrm{~g} \mathrm{~kg}^{-1}$ and IVDMD of $724 \mathrm{~g} \mathrm{~kg}^{-1}$ ) due to a transition in available
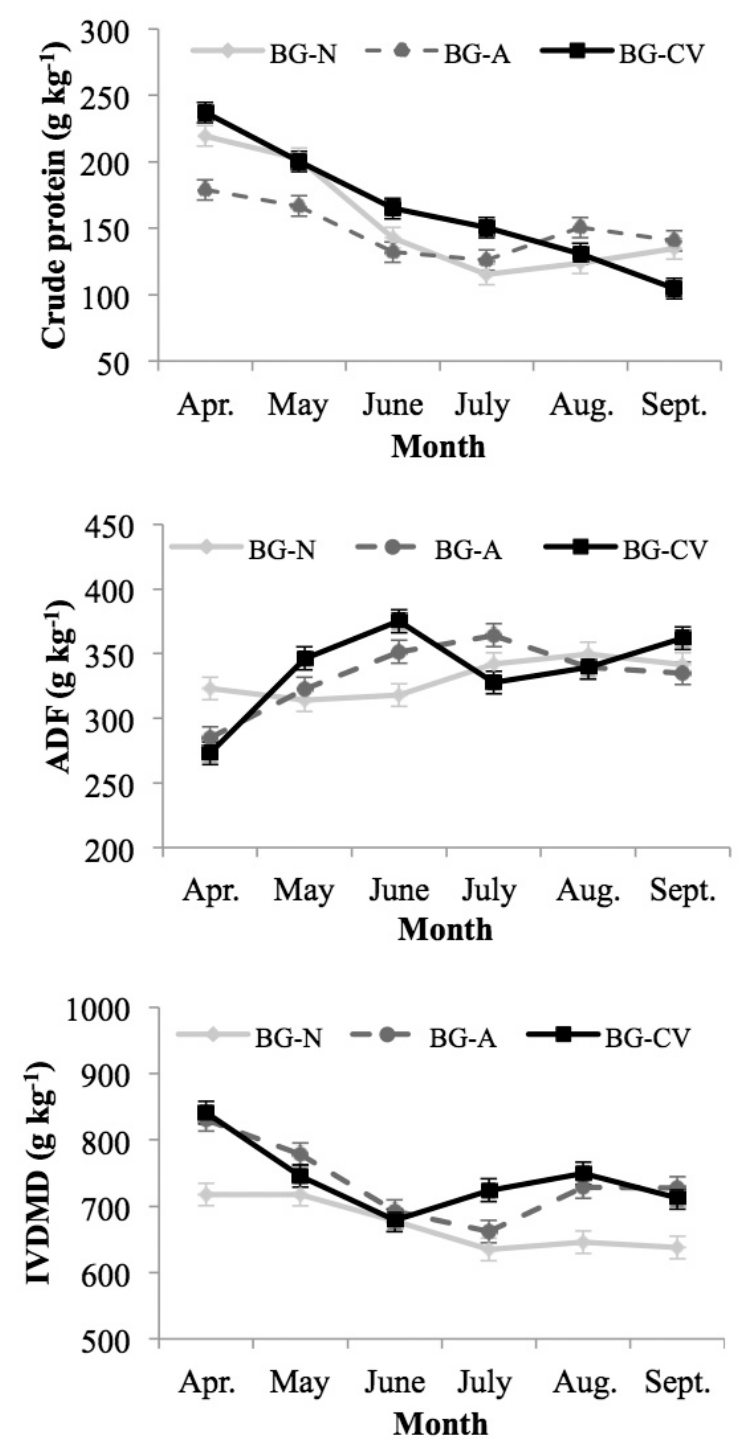

Figure 3. Seasonal changes in crude protein, acid detergent fiber (ADF), and in vitro dry matter digestibility (IVDMD) for the bermudagrass plus $112 \mathrm{~kg} \mathrm{~N} \mathrm{ha}^{-1}$ from urea (BG-N), bermudagrass interseeded with alfalfa (BG-A), and bermudagrass interseeded with clover and vetch (BG-CV) systems averaged across the 2008, 2009, and 2010 growing seasons.

forage from legumes to bermudagrass. Nutritive value then decreased again through the remainder of the season. In sum, however, these differences were not large enough to create differences in animal performance between systems, probably because nutrient values were generally adequate for steers gaining $0.68 \mathrm{~kg} \mathrm{~d}^{-1}\left(\sim 120 \mathrm{~g} \mathrm{CP} \mathrm{kg}^{-1}\right.$; National Research Council, 1996; Ball et al., 2007).

\section{Animal Performance}

Data reflecting animal performance measures are reported in Table 2. On average, cattle grazed from 23 May to 29 Aug (98 d), 29 Apr to $18 \mathrm{Jul}(80 \mathrm{~d})$, and 16 May to 1 Aug (77 d) for $\mathrm{BG}-\mathrm{N}, \mathrm{BG}-\mathrm{CV}$, and $\mathrm{BG}-\mathrm{A}$, respectively. On average, cattle grazing the $\mathrm{BG}-\mathrm{N}$ system realized a greater number of grazing days versus cattle grazing the BG-CV and BG-A 
Table 2. Expected values for costs, grazing duration, grazing days, stocking rate, average daily gain, total gain, value of gain, revenue, and net return for bermudagrass plus $112 \mathrm{~kg} \mathrm{~N} \mathrm{ha}^{-1}$ from urea (BG-N), bermudagrass interseeded with clover and vetch (BG-CV), or bermudagrass interseeded with alfalfa (BG-A).

\begin{tabular}{|c|c|c|c|}
\hline \multirow[b]{2}{*}{ Economic and animal performance variables } & \multicolumn{3}{|c|}{ System } \\
\hline & BG-N & BG-CV & BG-A \\
\hline Fertilizer and fertilizer application expenses $\left(\$ \mathrm{ha}^{-1}\right)$ & 148.20 & - & - \\
\hline Pesticide and pesticide application expenses $\left(\$ \mathrm{ha}^{-1}\right)$ & 18.53 & 40.92 & 40.92 \\
\hline Seed and seed establishment expenses $\left(\$ \mathrm{ha}^{-1}\right)$ & - & 164.29 & 413.58 \\
\hline Seed and seed establishment expenses amortized over 3 yr at $7.5 \%$ annual percentage rate $\left(\$ \mathrm{ha}^{-1}\right)$ & - & - & 159.04 \\
\hline Interest on annual operating capital $\left(\$\right.$ ha $\left.^{-1}\right)$ & 47.50 & 36.38 & 40.55 \\
\hline Total production cost $\left(\$ \mathrm{ha}^{-1}\right)$ & $214.23 \mathrm{a}^{\dagger}$ & $241.58 b$ & $240.15 b$ \\
\hline Initial cattle price $\left(\$ \mathrm{~kg}^{-1}\right)$ & $3.38 b$ & $3.42 \mathrm{a}$ & $3.38 b$ \\
\hline Final cattle price $\left(\$ \mathrm{~kg}^{-1}\right)$ & $3.13 c$ & $3.22 a$ & $3.18 b$ \\
\hline Grazing duration & 23 May-29 Aug. & 29 Apr.-18 July & 16 May-1 Aug. \\
\hline Steer grazing days $\left(\mathrm{d} \mathrm{ha}^{-1}\right)$ & $243 a$ & $184 \mathrm{c}$ & $221 \mathrm{~b}$ \\
\hline Stocking rate $\left(\text { head ha }{ }^{-1}\right)^{\ddagger}$ & 2.34 & 2.34 & 2.34 \\
\hline Average daily gain & $0.77 a$ & $0.80 a$ & $0.74 a$ \\
\hline Total gain & $187 a$ & $147 b$ & $163 a b$ \\
\hline Value of gain $\left(\$ \mathrm{~kg}^{-1}\right)$ & $2.37 a$ & $2.46 a$ & $2.01 \mathrm{~b}$ \\
\hline Revenue $\left(\$\right.$ ha $\left.^{-1}\right)$ & $426.16 \mathrm{a}$ & $371.86 a b$ & $317.66 b$ \\
\hline Net return to land, labor, management, and overhead $\left(\$ \mathrm{ha}^{-1}\right)$ & $211.68 \mathrm{a}$ & $130.02 \mathrm{ab}$ & $86.39 \mathrm{~b}$ \\
\hline
\end{tabular}

†Letters that differ across systems are significantly different at a 95\% level of confidence.

¥Stocking rate was fixed at four head per paddock in 2008 and three head per paddock in 2009 and 2010.

systems; however, average daily gain was similar (0.74 to 0.80 $\left.\mathrm{kg} \mathrm{head}^{-1} \mathrm{~d}^{-1}\right)$ for all three systems. Due to a greater number of grazing days on the BG-N system $\left(243 \mathrm{~d} \mathrm{ha}^{-1}\right)$, the total gain per hectare realized by cattle grazing the $\mathrm{BG}-\mathrm{N}$ system $\left(187 \mathrm{~kg} \mathrm{ha}^{-1}\right)$ was greater than the BG-CV $\left(147 \mathrm{~kg} \mathrm{ha}^{-1}\right)$ and BG-A $\left(163 \mathrm{~kg} \mathrm{ha}^{-1}\right)$ system.

\section{Economics}

Mean cattle prices used to place initial and ending value on cattle, calculated value of gain, gross revenue, operating costs, total costs, and net returns are reported in Table 2. Initial placement price (on price) and ending price (off price) of cattle for the BG-CV system were greater ( $p<$ $0.05)$ than the BG-N and BG-A systems, respectively. This difference is due to differences in the cattle placement and removal dates associated with the annual clover-vetch system relative to the other two systems. On average, value of gain for the BG-N and BG-CV systems were 15 and 18\% greater, respectively, than the BG-A system $(p<0.05)$. Much of this difference is related to differences in ending weights and hence overall total kilograms gain per hectare between systems, but some of it is due to differences in cattle prices. Risk management practices can be used to hedge against price volatility, which can help reduce variation in value of gain between systems due to prices. However, only a portion of this variation can be managed. Other parts of the variation are simply due to normal cyclical patterns in prices during a grazing period and differences in total animal gain between systems.

The 3-yr average gross revenue $\left(\$ \mathrm{ha}^{-1}\right)$ for the $\mathrm{BG}-\mathrm{N}$ system $\left(\$ 429.16 \mathrm{ha}^{-1}\right)$ was 16 and $34 \%$ greater $(p<0.05)$ than the BG-CV and BG-A systems, respectively. This is primarily the result of cattle in the BG-N system having access to a greater amount of forage for more days than the two bermudagrass-legume systems. Average 3-yr gross revenue for the BG-A system was lower than BG-N system, essentially due to a stand failure in the first year of the study. As a result, the bermudagrass forage did not receive a benefit from the $\mathrm{N}$-fixing legume nor did cattle receive additional benefit from additional forage from legumes early in the grazing season. Consequently, the BG-A system in the first season was essentially comparable to a bermudagrass system receiving a zero level of $\mathrm{N}$ fertilizer. It is important to note that the variation in growing conditions (rainfall) in the region was evident in this study. As such, the results reflect the typical risks associated with growing conditions common to the region.

When the cost $\left(\$ \mathrm{ha}^{-1}\right)$ of establishing alfalfa (seed and seed establishment expenses) was amortized over the 3 -yr life of the stand, the total cost of the BG-A system $\left(\$ 240.15 \mathrm{ha}^{-1}\right)$ was $11 \%$ greater $(p<0.05)$ than the BG-N $\left(\$ 214.23 \mathrm{ha}^{-1}\right)$ but similar to the BG-CV system $\left(\$ 241.58 \mathrm{ha}^{-1}\right)$. Due to stand failure in the first year the cost of establishing alfalfa had to be accounted for twice in the analysis. It is worth reemphasizing that the establishment failures of perennial crops such as alfalfa remain a real risk that producers face in the region, and hence the $2-y r$ establishment cost is probably a better measure of the expected costs associated with this system. The opportunity costs associated with owning the steers during the grazing period and the herbicide expenses for broadleaf weed management were considered to be annual expenses and therefore were not amortized in the analysis. Herbicide management is necessary to control for broadleaf weeds and to help control other grasses, which 
can effectively choke out legumes if not managed properly. Overall, the expected profitability favored the conventional system of applying synthetic $\mathrm{N}$ on bermudagrass. The average 3-yr net return for the BG-N system $\left(\$ 211.68 \mathrm{ha}^{-1}\right)$ and the BG-CV $(\$ 130.02)$ were greater $(p<0.05)$ than the BG-A (\$86.39 ha $\left.{ }^{-1}\right)$ system.

Results of extensive sensitivity analysis show that the estimates of expected profitability between the BG-CV and BG-N systems would become equal when the price on $\mathrm{N}$ reached $\$ 1.94 \mathrm{~kg}^{-1}$, or $60 \%$ greater than current $\mathrm{N}$ prices. Furthermore, the break-even price of $\mathrm{N}$ in terms of the $\mathrm{BG}-\mathrm{A}$ system is $\$ 2.32 \mathrm{~kg}^{-1}$. Due to greater management requirements associated with the legume systems, it is unlikely that producers will adopt the legume system until the price of $\mathrm{N}$ substantially exceeds the break-even value. We also found that the BG-N system would achieve zero profits when the price of $\mathrm{N}$ reached $\$ 3.06 \mathrm{~kg}^{-1}$. Increasing the life of stand of alfalfa from 3 to $6 \mathrm{yr}$ improves the relative economics of the BG-A system but only slightly. In fact, an alfalfa stand life of $30 \mathrm{yr}$ would be required for the BG-A system to break even with the BG-N system. The relative profitability of the BG-A system compared to the conventional $\mathrm{BG}-\mathrm{N}$ system is also sensitive to the retail price of alfalfa seed (the 2011 price of $\$ 17.97 \mathrm{~kg}^{-1}$ PLS was used in the base model). The results show that the profitability of the BG-A and BG-N systems would be equal for an alfalfa seed price of $\$ 1.54 \mathrm{~kg}^{-1} \mathrm{PLS}$, holding all other factors constant. One of the issues with alfalfa seed prices is that it tends to trend in stride with the price of $\mathrm{N}$; that is, when the price of $\mathrm{N}$ increases, so does the price of alfalfa (and other legume) seed.

Sensitivity analysis also revealed that differences in expected profitability among the three systems are very sensitive to a producer's ability to successfully establish alfalfa in the first year. That is, we found that if alfalfa had been successfully established in the fall of 2007, then the expected net return of that system would have been $\$ 165.91$ instead of $\$ 86.9 \mathrm{ha}^{-1}$. At this net return for the BG-A system, the differences in expected net return between the three systems are not significant but do remain numerically different in favor of the conventional $\mathrm{N}$ system. It is important to reemphasize that currently, managing synthetic $\mathrm{N}$ sources is relatively simple for most producers. In fact, this activity often only requires producers to make a phone call and request that a local fertilizer dealer come out and apply $\mathrm{N}$ to their pastures. Both legume systems require additional management effort on the part of producers and this effort must acknowledged in the decision for which system to adopt. If producers are willing to accept the increased management required of legume-grass systems and possibly other increased management (i.e., rotational grazing), legume systems deserve some consideration.

Sensitivity analysis also revealed that the relative expected profitability between the three systems is sensitive to differences in the expected purchase and sale prices of cattle between systems. We note that the expected placement (on) dates for cattle in the BG-N and BG-A systems are similar, so we assume that producers are able to purchase similar type of cattle for these two systems at the same price. However, the expected placement date for the annual BG-CV system is at least, on average, $15 \mathrm{~d}$ earlier than the other two systems. If we assume that skilled producers (or order buyers) can purchase cattle for all three systems at the same price (i.e., the average price of $\$ 3.38 \mathrm{~kg}^{-1}$ ), then the expected profitability of the BG-CV system would increase from $\$ 130.02$ to $\$ 155.68 \mathrm{ha}^{-1}$, which is a $20 \%$ increase in the annual legume system's expected profit relative to the control system. For this case, there is no statistical difference in profitability between these two systems but there does remain a numerical difference of about $\$ 26 \mathrm{ha}^{-1}$ that favors the control system. Further analysis shows that producers using the annual legume system will have to be able to purchase cattle at a price of $\$ 3.55 \mathrm{~kg}$ in order for the profitability of BG-N and BG-CV to be equal.

Conversely, average sale price for cattle was different between all three systems (Table 2). In fact, sale price for the BG-A $\left(\$ 3.18 \mathrm{~kg}^{-1}\right)$ and BG-CV $\left(\$ 3.22 \mathrm{~kg}^{-1}\right)$ systems were greater than the sale price of the control system $(\$ 3.13$ $\left.\mathrm{kg}^{-1}\right)$. This implies that the two legume systems received a price advantage over the control. This is primarily due to the cyclical nature in the cattle market at different points in the year. Compared with the BG-N system, the breakeven sale prices of cattle produced in BG-CV and BG-A systems were $\$ 3.32$ and $\$ 3.34 \mathrm{~kg}^{-1}$, respectively. We expect that producers in this region are more likely to manage purchase and sale prices more efficiently for the control system relative to the alternative legume systems simply because they are more familiar with the conventional system. Also, based on these threshold prices, it seems that producers who have the ability to lock favorable market prices for their cattle may be able to realize a greater level of profitability from legumes than using $\mathrm{N}$, especially the annual legume system during periods in time when the price of $\mathrm{N}$ is relatively high compared to its trend price.

\section{CONCLUSIONS}

Based on this 3-yr, continuous grazing study conducted in growing conditions common to south-central Oklahoma, it appears that the two legume systems evaluated are not expected to be as profitable as the conventional practice of supplying synthetic sources of $\mathrm{N}$ to growing stands of bermudagrass, especially at a market price of $\$ 1.21 \mathrm{~kg}^{-1}$ of actual $\mathrm{N}$ (46\% urea). In addition, economic results for the legumes systems are also sensitive to cattle purchase and sale prices, the length of the grazing period, the prices of legume seeds, and a producer's ability to successfully establish alfalfa. Moreover, the additional management effort that is required for the legume systems is probably 
greater than the minimal effort required by farmers to have synthetic sources of $\mathrm{N}$ applied to their pastures at the convenience of a phone call. Lastly, legumes typically require higher soil quality (i.e., neutral soil $\mathrm{pH}$ ); therefore, acidic soils that require lime could affect the economics of these legume-bermudagrass systems, increasing the relative costs of the legume systems.

Replication of the study at additional sites and years would provide additional information about how results can be expected to vary under different soil types, environmental conditions, and grazing management strategies. In addition, more research is needed to identify legume species that may be more favorable for a bermudagrass-legume system.

\section{References}

Ball, D.M., C.S. Hoveland, and G.D. Lacefield. 2007. Southern forages, modern concept for forage crop management, 4th ed. Int. Plant Nutrition Inst., Norcross, GA.

Baylor, J.E. 1974. Satisfying the nutritional requirements of grasslegume mixtures. In: D.A. Mays, editor, Forage fertilization. ASA, CSSA, and SSSA, Madison, WI. p. 171-188.

Bouton, J.H., and R.N. Gates. 2003. Grazing-tolerant alfalfa cultivars perform well under rotational stocking and hay management. Agron. J. 95(6):1461-1464. doi:10.2134/ agronj2003.1461

Cassida, K.A., C.B. Stewart, V.A. Haby, and S.A. Gunter. 2006. Alfalfa as an alternative to bermudagrass for pastured stocker cattle systems in the southern USA. Agron. J. 98:705-713. doi:10.2134/agronj2005.0081

Crosby, B., K. Swanser, J. Mangus, C. Crosby, K.C. Dhuyvetter, T. Kastens, and J. Minert. 2005. BeefBasis.com: Decision support for America's beef producers. http://www.beefbasis. com/ (accessed 15 Mar. 2011). Custom Ag Solutions, Inc., Cowley, WY, and Kansas State University, Manhattan, KS.

Dalrymple, R.L. 1998. Controlled rotational grazing unit. Samuel Roberts Noble Foundation Press, Agriculture Division Publication, Ardmore, OK. http://www.noble.org/ag/ forage/rotation/forgcrgu.htm (accessed 15 Jan. 2010)

Doye, D., and R. Sahs. 2010. Oklahoma farm and ranch custom rates, 2009-2010. Oklahoma Cooperative Extension, Current Report CR-205-0310. Oklahoma State University Press, Stillwater, OK.

Greene, W. 2005. Econometric analysis, 5th ed. Prentice Hall, Upper Saddle River, NJ. p. 484-486.

Hoveland, C.S. 1989. Legume persistence under grazing in stressful environments in the USA. In: G.C. Marten et al., editors, Persistence of forage legumes. ASA, CSSA, and SSSA, Madison, WI. p. 375-385.

National Research Council. 1996. Nutrient requirements of beef cattle, 7th ed. Natl. Acad. Press, Washington, DC.

Oklahoma Cooperative Extension Service (OCES). 2012. Dryland bermudagrass enterprise budget - Graze only. Oklahoma State University, Agricultural Economics Department, Stillwater, OK. http://agecon.okstate.edu/budgets/sample\%20files/ PerennialForage2.1\%20PastureSummary.pdf (accessed 15 Sept. 2011).

Rao, S.C., B.K. Northup, W.A. Phillips, and H.S. Mayeux. 2007. Interseeding novel cool-season annual legumes to improve bermudagrass paddocks. Crop Sci. 47:168-173. doi:10.2135/ cropsci2006.02.0088

SAS Institute. 2002. SAS proprietary software, version 9.1. SAS Inst., Cary, NC.

Smith, S.R., Jr., and J.H. Bouton. 1993. Selection within alfalfa cultivars for persistence under continuous stocking. Crop Sci. 33:1321-1328. doi:10.2135/cropsci1993.0011183X003300060 $040 \mathrm{x}$

USDA. 2009. Agricultural prices 2008 summary. Pr 1-3(09). National Agricultural Statistics Service, Washington, DC. http://usda.mannlib.cornell.edu/usda/nass/ AgriPricSu//2000s/2009/AgriPricSu-08-05-2009.pdf (accessed 15 Nov. 2009).

Zhang, H., B. Raun, and B. Arnall. 2009. OSU soil test interpretations. PSS-2225. Oklahoma Coop. Ext. Serv., Stillwater, OK. http://pods.dasnr.okstate.edu/docushare/ dsweb/Get/Document-1490/PSS-2225web.pdf (accessed 30 Aug. 2010). 